\title{
BEBERAPA TEKNIK TRANSPORTASI IKAN LAUT HIDUP DAN FASILITASNYA PADA PERDAGANGAN IKAN LAUT DI BELITUNG
}

\author{
Philip Teguh Imanto* \\ * Balai Besar Riset Perikanan Budidaya Laut, Gondol
}

\begin{abstract}
ABSTRAK
Permintaan produk perikanan laut di masa datang tidak dapat dipenuhi hanya dari hasil penangkapan, sehingga produksi hasil budidaya akan memegang peranan sangat penting pada pemenuhan kebutuhan ikan yang berkualitas, karena dapat disampaikan dalam kondisi hidup. Teknik transportasi ikan laut hidup menjadi faktor utama bagaimana menyampaikan produk budidaya sebaik mungkin. Observasi pada kegiatan transportasi ikan laut hidup dilakukan di wilayah budidaya laut di Belitung bertujuan untuk mengetahui perkembangan teknologi transportasi ikan laut hidup dan faktor-faktor penting dalam penyelenggaraannya. Wawancara dan dokumentasi dilakukan sebagai cara untuk menghimpun data dan informasi. Hasil observasi menunjukkan ada tiga bentuk teknik transportasi ikan laut hidup di wilayah Belitung, yaitu transportasi laut, transportasi darat, dan transportasi udara. Faktor yang berperan pada transportasi ikan laut hidup adalah kualitas media, pemuasaan, pendinginan, pembiusan, oksigenasi, dan kadar garam. Faktor-faktor tersebut berkaitan dengan proses-proses pencernaan, metabolisme hingga konsumsi oksigen. Butir penting dari transportasi ikan laut hidup adalah menurunkan tingkat konsumsi oksigen serendah mungkin, meniadakan pencemaran pada media pengangkut, menstabilkan kondisi oksigen terlarut dan suhu media pengangkut, serta meningkatkan daya angkut.
\end{abstract}

KATA KUNCl: transportasi, ikan laut hidup

\section{PENDAHULUAN}

Permintaan produk perikanan laut terus mengalami peningkatan, proyeksi permintaan produk perikanan dunia sampai pada tahun 2025 adalah sekitar 115 juta ton (Csavas dalam INFOFISH 5/94). Produksi dari penangkapan dibatasi pada batas lestari yang bisa dimanfaatkan (M inimum Sustainable Yield), sehingga strategi pengembangan produk perikanan sudah seharusnya diarahkan sejak dini pada budidaya laut. Bagi Indonesia, marikultur merupakan usaha yang sangat menjanjikan, mengingat keunggulan komparatif dalam bentuk sumberdaya lahan dan hayati yang dimiliki serta kondisi iklim tropis (Nurdjana, 2001). Beberapa komoditas perikanan laut bernilai sangat tinggi seperti ikan kerapu lumpur, kerapu sunu, kerapu tikus, ikan lemak/ napoleon, terutama bila dipasarkan dalam kondisi hidup. Pada tahun 2007 terpantau harga berkisar Rp 60.000,--Rp 380.000,-/kg. di pasar lokal, dan antara Rp 80.000,--Rp 450.000,- di pasar internasional (hasil komunikasi dengan beberapa pelaku perdagangan ikan laut di Belitung dan Jakarta).

Produk marikultur merupakan barang komersial yang cepat mengalami kerusakan (mudah membusuk) mengingat sifat alami produk ini, upaya menjaga mutu adalah menyampaikan produk tersebut dalam keadaan hidup ke konsumen (Sudradjat et al., 1999). Keadaan ini menuntut terintegrasinya berbagai kegiatan maupun bidang keahlian seperti teknologi proses hingga teknologi pengangkutan/transportasi dari produk tersebut yang dapat terdiri atas teknologi dan manajemen kemasan, serta alat angkut. Persaingan global menuntut digunakannya alat angkut yang cepat sehingga produk marikultur sampai di tangan konsumen dalam keadaan hidup, karena akan menentukan tingginya nilai jual pasar (Anonymous, 1986).

Penelitian dan pengembangan metode dan teknik transportasi ikan laut hidup, telah dimulai oleh beberapa peneliti di antaranya; transportasi ikan kerapu dengan beberapa sistem kemasan (Suryaningrum et al., 2000 $\&$ $2000^{\text {b; }}$ Suryaningrum \& Utomo, 2001), transportasi udang karang/lobster (Suryaningrum et al., 1997), tetapi masih sangat sedikit dibanding penelitian perikanan lainnya.

Dalam tulisan ini disampaikan beberapa perkembangan teknik transportasi ikan laut hidup yang telah dilakukan pada kegiatan budidaya laut dan perdagangan ikan laut di Belitung, yang diharapkan dapat digunakan sebagai bahan kajian dan pembanding dalam pengembangan teknologi transportasi ikan laut. 


\section{METODE}

Lokasi penelitian di wilayah Belitung dan perairan sekitarnya, terutama pada sentra-sentra kegiatan budidaya ikan laut di keramba jaring apung maupun kegiatan perdagangan ikan laut hidup.

Beberapa metode penelitian dilakukan pada kegiatan ini, dan terdiri atas:

- Observasi dilakukan untuk mengidentifikasi jenisjenis teknik transportasi pada kegiatan budidaya ikan laut di keramba jaring apung dan perdagangan ikan laut.

- Wawancara dengan pelaku kegiatan untuk mengetahui prosedur kegiatan dari masing-masing teknik transportasi.

- Pengukuran dan dokumentasi dari peralatan dan pelaksanaan kegiatan transportasi.

- Tinjauan pustaka untuk mengetahui dasar dan landasan dari setiap perlakuan pada kegiatan transportasi.

Pengolahan dokumentasi digital menggunakan perangkat lunak Ulead Photo Explorer 7.0 SE dan Microsoft Photo Editor, dan Microsoft Word dari M icrosoft Office 2000 Premium digunakan dalam penyusunan laporan.

\section{HASIL DAN BAHASAN}

Dari hasil observasi pada beberapa kegiatan budidaya laut dan perdagangannya, berhasil dihimpun informasi tentang teknik transportasi ikan laut yang dipisahkan menurut areanya, yaitu transportasi laut, darat, dan melalui udara.

\section{Transportasi Laut}

Pada umumnya transportasi laut di perairan Belitung dilakukan untuk memindahkan ikan antar keramba jaring apung (KJA) atau ke lokasi penampungan di darat. Transportasi laut menggunakan kapal yang memiliki palka sirkulasi satu atau dua unit, volume bervariasi dari 1 hingga 3 mºunit.

Palka sirkulasi pada kapal perikanan di perairan Belitung (Gambar 1), umumnya terbuat dari papan dengan ketebalan 3--5 cm yang lebih berupa penyekat pada lambung kapal, dan pada dasar lambung dibuat empat lubang ( $\varnothing 2$ inci). Dilengkapi pula dengan pemipaan PVC yang dapat diatur arahnya (Gambar 2) untuk memasukkan dan mengeluarkan air laut pada saat kapal berjalan. Alat lain yang melengkapi adalah pompa air laut jinjing (portable water pump) dengan penggerak motor bensin, yang digunakan pada saat kapal dalam posisi tidak bergerak.

Kemampuan angkut sangat tergantung pada kecepatan kapal dan besarnya air yang mampu disirkulasikan, pada umumnya terdapat pada kisaran angka 10\%-20\% dari volume palka. Dari catatan selama mengikuti kegiatan transportasi laut, diketahui debit air yang dapat dialirkan/ disirkulasikan dari 2 pipa pemasukan dengan kecepatan 4--6 knot dapat dihasilkan debit sebesar 2--3 m³/jam.

\section{Transportasi darat}

Transportasi darat (tanpa sirkulasi air) dilakukan dengan menggunakan tangki serat kaca (fiber glass) yang dilengkapi dengan pasok oksigen murni, dan diangkut menggunakan truk. Volume tangki bervariasi 1,5 hingga $2,0 \mathrm{~m}^{3}$.

Pada umumnya transportasi darat dengan menggunakan tangki tertutup dibedakan menurut jarak tempuhnya. Jarak pendek (kurang dari 3 jam) tidak menggunakan pendinginan, sedang untuk jarak jauh (lebih dari 3 jam) dilakukan pendinginan dengan penambahan es balok hingga suhu air turun antara $22^{\circ} \mathrm{C}-23^{\circ} \mathrm{C}$. Tangki diisi dengan air laut yang telah difiltrasi hingga penuh sampai lubang tangki di atas, hal ini penting untuk menjaga agar tidak terjadi goncangan massa air pada saat transportasi berjalan. Dengan kondisi air yang lebih tenang ikan-ikan tidak mengalami stres dan aktivitas berlebihan yang berkaitan dengan konsumsi oksigen. Pasok oksigen dari gas oksigen murni yang diatur pengeluarannya dengan gas regulator dan diukur volumenya dengan flowmeter (Gambar 3).

Ikan kerapu sunu ukuran pasar 0,8--1,2 kg dapat diangkut sebanyak 300 ekor, yang berarti daya dukung media air dalam tangki mencapai 15\%-20\%dari volumenya. Pada pengangkutan darat (tertutup) ikan yang akan diangkut harus dipuasakan selama 2 hari untuk memastikan tidak terjadinya pengotoran media air laut pengangkut.

\section{Transportasi udara}

Transportasi udara menggunakan box Styrofoam (volume $70 \mathrm{~L}$ ), kantong plastik sebagai penampung air laut, ikan, dan oksigen murni. Tahapan pengangkutan dimulai dengan aklimatisasi suhu sampai $20^{\circ} \mathrm{C}$ menggunakan tangki beton dengan sistem resirkulasi yang berpendingin (Gambar 4).

Operasional transportasi udara dimulai dari penyiapan air laut yang diresirkulasikan selama 48 jam terlebih dahulu (sebelum ikan dimasukkan) untuk memastikan air laut dalam kondisi bersih/jernih, kecepatan resirkulasi air mencapai 1,2 meter kubik air setiap jamnya atau 50\% dari volume tangki. Filtrasi yang digunakan cukup sederhana terdiri atas patahan karang jahe (coral branching), ijuk, dan pasir (kompartemen B) (Gambar 4). 


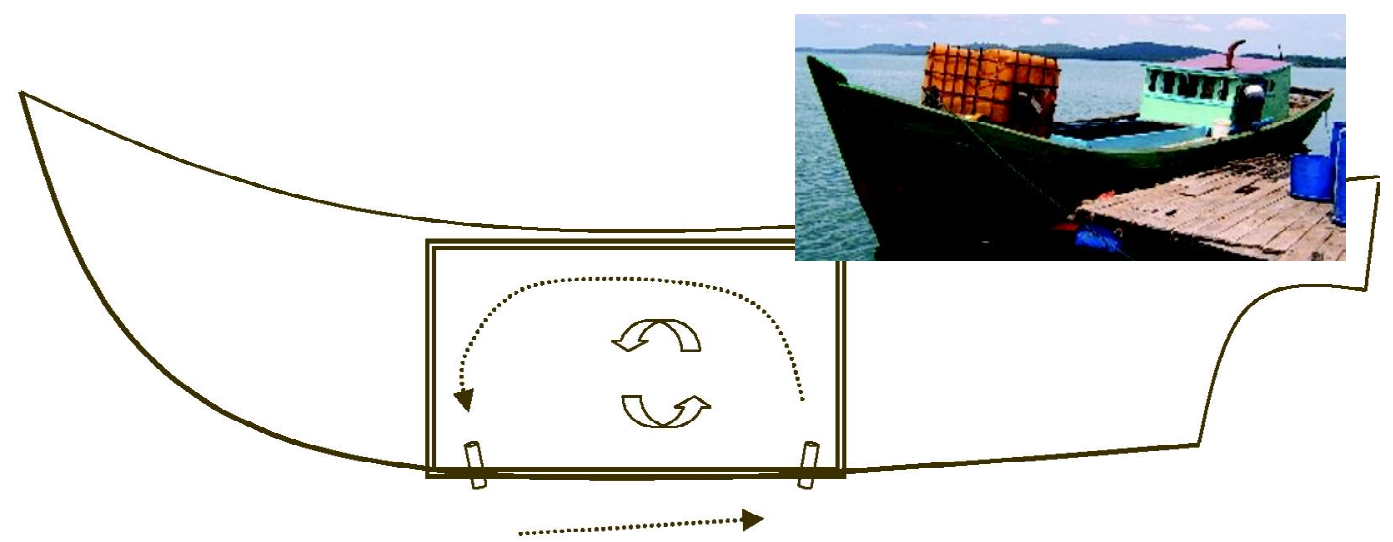

Gambar 1. Denah palka bersirkulasi pada lambung kapal ikan

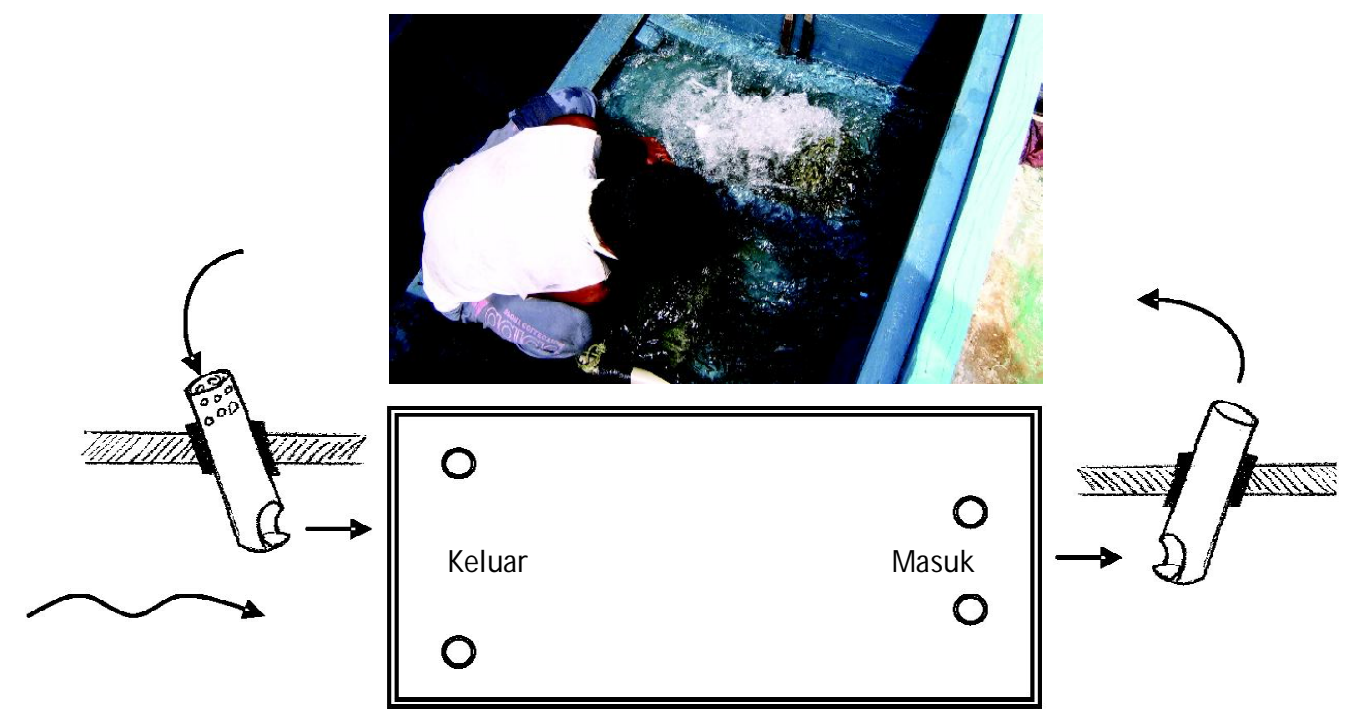

Gambar 2. Detail posisi dan bentuk pipa pemasukan dan pengeluaran pada dasar palka

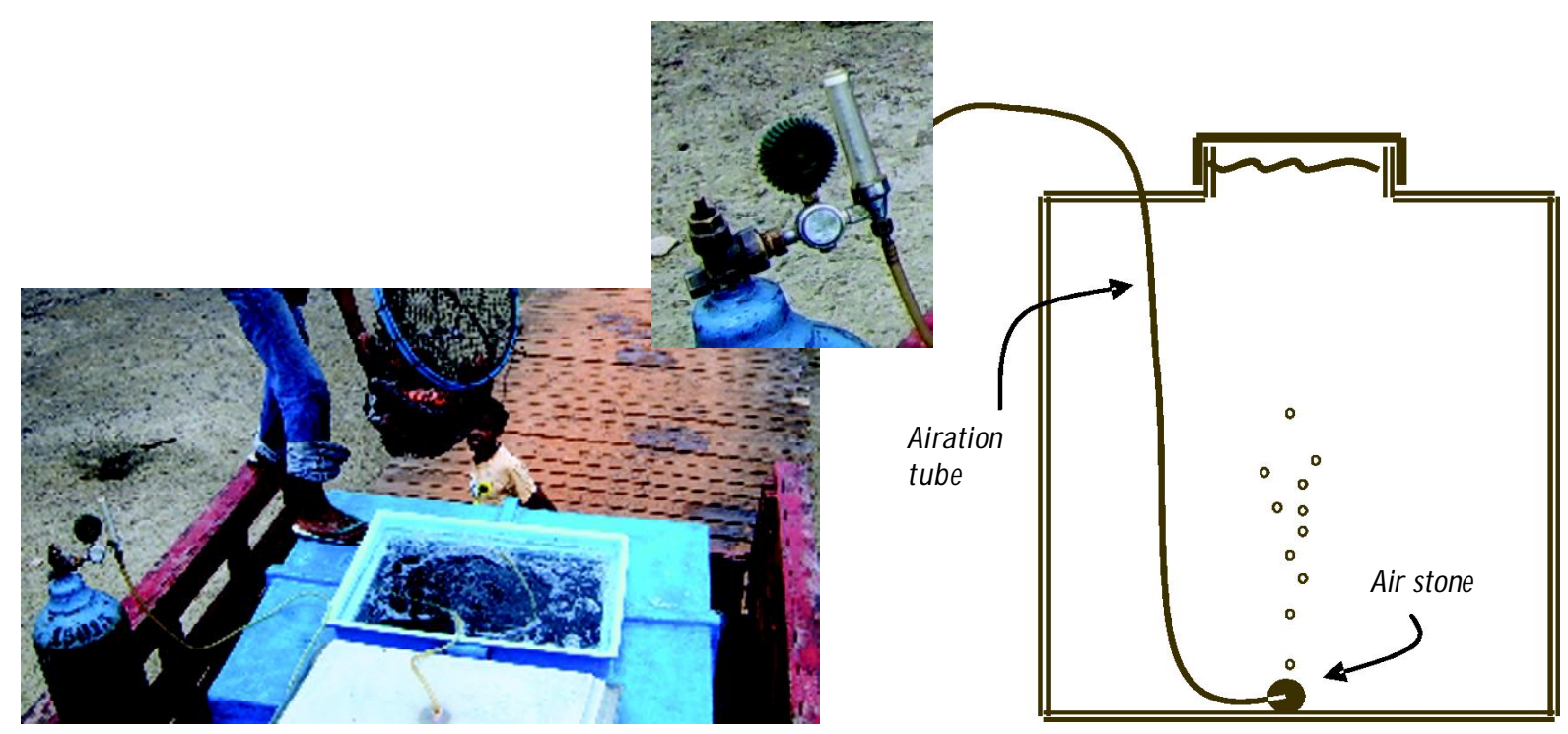

Gambar 3. Tangki serat kaca dan fasilitasnya pada transportasi darat 


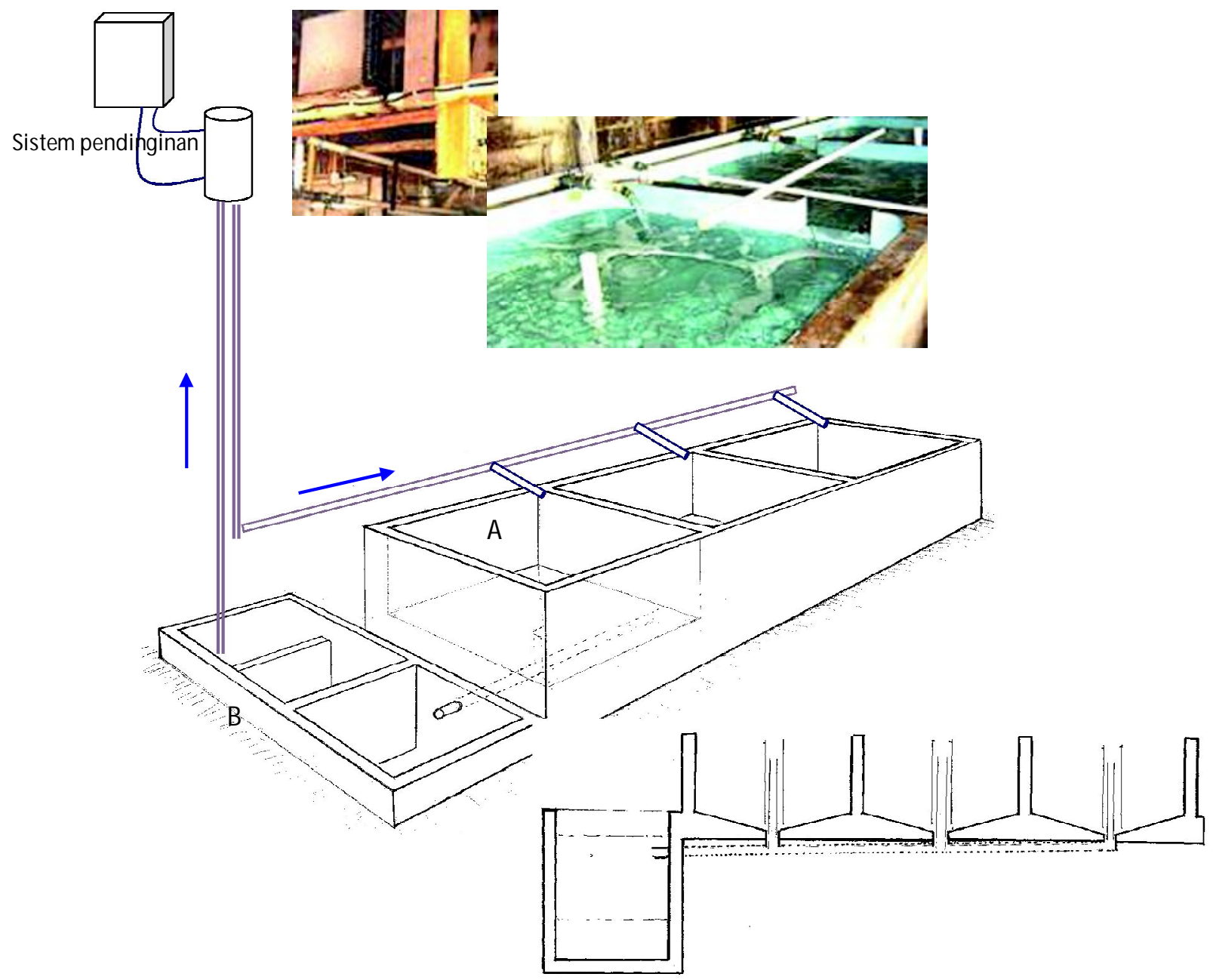

Gambar 4. Konstruksi tanki aklimatisasi (A), sistem filtrasi (B) dan sarana pendinginan

Ikan yang akan dikirim ditempatkan pada tangki aklimatisasi (kompartemen A) pada siang hari dan pada malam hari (pukul 20.00) sarana pendingin (cooling system) diaktifkan untuk menurunkan suhu air laut secara bertahap hingga mencapai $20^{\circ} \mathrm{C}$ pada pukul 04.00 .

Persiapan pengemasan dilakukan dengan menyiapkan kantong-kantong plastik dua lapis dalam setiap styrofoam box, dan diisi dengan air laut yang telah didinginkan mencapai $16^{\circ} \mathrm{C}$ sebanyak sepertiga dari volume boks ( \pm 16 L) (Gambar 5).

Air laut pada tangki aklimatisasi juga diturunkan lagi dengan pemberian es balok hingga tercapai suhu $16^{\circ} \mathrm{C}-$ $17^{\circ} \mathrm{C}$. Setelah suhu transportasi tercapai, mulai dilakukan pembiusan dengan quinaldine $( \pm 3 \mathrm{mg} / \mathrm{L}$ dari stock sulotion yang disiapkan oleh pengusaha dan kandungan bahan aktif tidak diketahui/dirahasiakan).

Ikan-ikan yang telah tertidur dimasukkan ke dalam kemasan kantong plastik dengan perhitungan mencapai bobot $8 \mathrm{~kg}$ biomassa setiap boks, kemudian gas oksigen diinjeksikan kedalam kantong plastik dan kantong diikat kuat satu per satu. Selanjutnya boks ditutup rapat dan dibungkus plastik lagi dibagian luar (standar cargo udara untuk ikan hidup) dan styrofoam box siap ditransportasikan melalui pesawat. Berdasarkan pengalaman dari pengelola ikan-ikan kerapu sunu, Plectropomus leopardus mampu bertahan hingga 16 jam.

\section{Faktor penting pada transportasi}

Dari semua kegiatan transportasi ikan laut hidup, diketahui beberapa faktor yang menentukan keberhasilannya, yaitu: sirkulasi media pada transportasi laut; pemuasaan, pendinginan, dan pasok oksigen pada transportasi darat; pemuasaan suhu, media pembiusan, penurunan salinitas, ratio volume ikan, serta media dan oksigen pada transportasi udara.

\section{Sirkulasi media air laut}

Pada transportasi laut umumnya memerlukan waktu tempuh yang relatif lama, dan ikan yang diangkut pada 

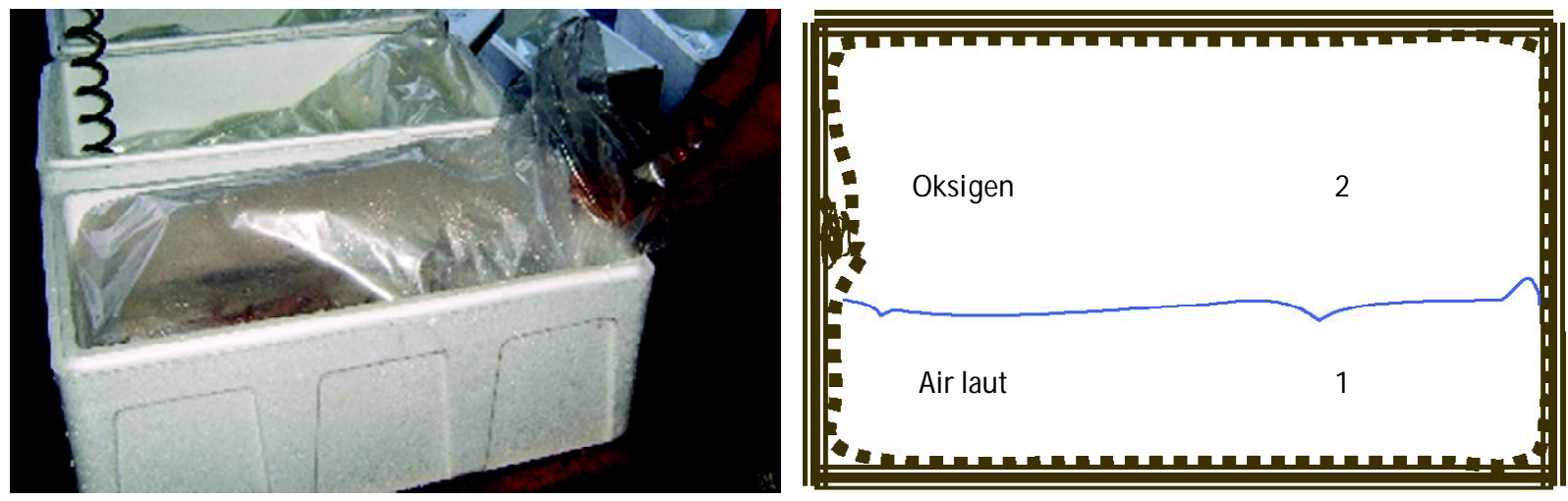

Gambar 5. Kotak styrofoam, posisi kantong plastik kemasan, dan perbandingan volume media air laut dan oksigen

umumnya tanpa dipuasakan, sehingga sirkulasi air adalah hal vital untuk selalu memasok air baru dan mengangkut keluar hasil sisa metabolisme (kotoran) selama perjalanan. Yang paling penting disini adalah menjaga pasok oksigen dan mengeliminir penumpukan amonia. Amonia dalam bentuk $\mathrm{NH}_{3}$ bersifat racun (toxic) dan membahayakan bagi ikan, meskipun masing-masing jenis ikan memiliki ketahanan yang berlainan, oleh karena itu amonia harus secepatnya disingkirkan dengan cara pergantian air baru (Wedemeyer, 1996).

\section{Pemuasaan}

Pemuasaan dalam jangka waktu tertentu, bertujuan menurunkan proses pencernaan, baik yang bersifat mekanik maupun kimiawi, yang mengubah makanan menjadi bahan yang mudah diserap dan diedarkan ke seluruh tubuh melalui darah.

Pada proses pencernaan akan dibutuhkan energi yang secara langsung berkaitan dengan kebutuhan oksigen, di mana oksigen diperlukan pada proses oksidasi untuk memproduksi bioenergi dari penguraian bahan makanan (Fujaya, 1999), sehingga dengan tiadanya bahan yang harus dicerna, secara tidak langsung juga akan menurunkan kebutuhan oksigen. Ketiadaan bahan untuk dicerna juga akan meniadakan sisa hasil pencernaan yang berupa kotoran, kencing, dan energi panas yang berpotensi meningkatkan kekeruhan, konsentrasi amonia, dan kenaikan suhu pada media pengangkutan.

Amonia yang dihasilkan dari sisa pencernaan dan metabolisme dilaporkan bersifat racun pada tingkat 0,6 $\mathrm{mg} / \mathrm{L}$ dalam media air. Semakin tinggi konsentrasinya di dalam media air, mengakibatkan amonia darah meninggi yang berdampak pada peningkatan $\mathrm{pH}$ darah sehingga mempengaruhi reaksi berantai enzim pada kegiatan metabolisme. Pemuasaan dan penurunan suhu media akan mengurangi pengeluaran amonia (Anonymous, 1986).

\section{Pendinginan Suhu Media}

Suhu media secara fisik berpengaruh pada tingkat keterlarutan oksigen di dalam air, semakin dingin suhu air, konsentrasi oksigen terlarut akan semakin tinggi (Tabel 1) (Schmittou, 1991). Suhu juga berperanan secara biologis pada aktivitas peredaran darah ikan, proses pencernaan dan metabolisme. Setiap peningkatan suhu media akan menyebabkan peningkatan aktivitas metabolisme dan mengurangi kelarutan oksigen, dan metabolisme yang tinggi mempercepat penurunan kualitas air oleh senyawa metabolit (Suparno \& Irianto, 1995). Suhu media yang dingin secara langsung akan mempengaruhi suhu badan ikan dan suhu darah, semakin dingin suhu darah tingkat viskositas darah akan mengental dan mengakibatkan aliran darah yang lebih lambat (Fujaya, 1999). Pada proses pencernaan, suhu tubuh berperan pada pengeluaran sekresi asam lambung untuk proses pencernaan, yang menurun pada suhu rendah, dan secara simultan berpengaruh pada proses pencernaan dan metabolisme. Menurunnya proses metabolisme mengakibatkan menurunnya kebutuhan bioenergi dan secara langsung berdampak pada menurunnya kebutuhan oksigen.

Penurunan suhu berdampak pada penurunan konsumsi oksigen dan menurunnya produk metabolisme yang dapat bersifat racun (toxic) baik dalam bentuk gas $\mathrm{CO}_{2}$ maupun amonia dalam bentuk $\mathrm{NH}_{3}$ (Wedemeyer, 1996).

\section{Pasok Oksigen}

Konsumsi oksigen untuk respirasi tergantung pada jenis dan ukuran ikan dalam kaitannya dengan tingkat aktivitasnya. Suparno \& Irianto (1995) menyatakan kebutuhan spesifik untuk tiap jenis ikan sangat penting untuk diketahui, sehingga perhitungan pasok oksigen untuk transportasi ikan laut dapat dilakukan secara optimal. 
Tabel 1. Konsentrasi oksigen terlarut pada beberapa suhu air laut dan salinitasnya

\begin{tabular}{cccc}
\hline & \multicolumn{3}{c}{$\begin{array}{c}\text { DO (mg/L) } \\
\text { dalam air laut (ppt) }\end{array}$} \\
\cline { 2 - 4 } Suhu $\left({ }^{\circ} \mathbf{C}\right)$ & $\mathbf{5}$ & $\mathbf{2 0}$ & $\mathbf{3 5}$ \\
\hline 15 & 9,8 & 8,9 & 8,1 \\
20 & 8,8 & 8,1 & 7,4 \\
25 & 8 & 7,4 & 6,8 \\
30 & 7,3 & 6,8 & 6,2 \\
\hline
\end{tabular}

Schmittou (1991)

Oksigen sebagai bahan pernapasan diperlukan sel untuk melakukan reaksi metabolisme, dan masuknya oksigen ke dalam darah melalui alat pernapasan (insang) yang efektifitasnya dipengaruhi struktur alat pernapasan itu sendiri serta perbedaan tekanan parsial $\mathrm{O}_{2}$ antara perairan dengan darah. Insang terbentuk dari lengkungan tulang rawan yang mengeras dengan beberapa filamen insang, dan tiap filamen tersusun dari banyak lamella sebagai tempat pertukaran gas. Struktur lamella tersusun dari sel-sel epitel yang tipis, membran dasar dan sel-sel penyangga, serta dipenuhi oleh epitelium dengan pembuluh darah kapiler pada bagian tepi lamella (Fujaya, 1999). Semakin banyak jumlah dan semakin besar lamella akan semakin efisien terjadinya pertukaran gas dari perairan ke darah.

Tekanan parsial gas berbanding lurus dengan konsentrasi molekulnya, sehingga semakin tinggi konsentrasi/keterlarutan gas, tekanan parsialnya juga semakin tinggi dan semakin mudah untuk terjadinya difusi oksigen dari perairan ke insang dan ke darah.

Pasok oksigen murni bertujuan meningkatkan konsentrasi oksigen terlarut sehingga meningkatkan tekanan parsial gas oksigen di dalam air untuk meningkatkan proses difusi oksigen ke dalam darah.

\section{Pembiusan}

Pembiusan dapat dilakukan dengan berbagai jenis obat bius, mulai dari ethylene glycol mono phenyl ether, tricaine methenesulfonate(MS-222), quinaldine, dan phenoxyethanol.

Tujuan utama pembiusan adalah membuat ikan tertidur atau pingsan dan dalam kondisi tersebut akan menurunkan tingkat metabolisme yang mengakibatkan berkurangnya kebutuhan oksigen dan menurunkan produksi amonia dan karbondioksida (Wedemeyer, 1996).

Teknik pembiusan juga telah dilakukan oleh Surono et al. (1995) untuk menurunkan kemungkinan stres dan cacat pada ikan saat panen hingga penanganan dan pengemasan. Pembiusan mencegah ikan dari stres karena gerakan yang sangat aktif (hyperactivity) (Anonymous, 1986). Akibat dari stres pada ikan akan menurunkan daya tahan terhadap penyakit yang dapat ditimbulkan dari mikroba ataupun bakteri yang terdapat secara alamiah pada ikan (Suparno \& Irianto, 1995).

\section{Penurunan kadar garam}

Pada transportasi udara, termonitor pemberian es balok yang cukup banyak untuk menurunkan suhu air sampai mencapai $16^{\circ} \mathrm{C}-17^{\circ} \mathrm{C}$, yang secara tidak langsung menurunkan kadar garam pada tangki aklimatisasi. Sedangkan pendinginan air laut untuk pengemasan hanya menggunakan es balok (air tawar) sehingga dapat dipastikan kadar garam akan turun cukup nyata. Penurunan kadar garam akan memberi dampak positif dan berkaitan erat dengan fisiologis ikan yaitu kinerja osmoregulasi.

Tekanan osmotik dari air laut lebih tinggi dibanding cairan tubuh pada ikan, sehingga secara alami air dalam tubuh akan mengalir keluar secara osmosis. Hal tersebut untuk mempertahankan konsentrasi garam dan cairan tubuhnya ikan laut teleostei oseanodrom meminum air laut cukup banyak yang dalam kondisi normal mencapai $10 \mathrm{~mL} / 100 \mathrm{~g} / \mathrm{jam}$ (Fujaya, 1999) dan melakukan osmoregulasi untuk mengatur jumlah cairan dan konsentrasi garam dalam tubuhnya, dan kegiatan osmoregulasi ini memerlukan energi metabolisme. Semakin jauh perbedaan tekanan osmose antara lingkungan dan tubuh, akan semakin banyak energi metabolisme yang diperlukan, yang tentunya berdampak pada peningkatan kebutuhan oksigen. Sehingga penurunan kadar garam media pengangkut akan berdampak pada menurunnya aktivitas osmoregulasi dan kebutuhan energi metabolisme.

\section{Padat pengangkutan}

Secara umum jumlah ikan yang dapat diangkut tergantung pada ukurannya, ikan kecil/benih akan dapat diangkut lebih banyak dibanding ikan besar ukuran pasar, tetapi total bobot ikan yang dapat diangkut per satuan volume media pengangkutan akan lebih tinggi pada ikan-ikan berukuran besar. Suparno \& Irianto (1995) menyatakan bahwa daya angkut dapat dinaikkan hingga $25 \%$ untuk setiap penurunan suhu air $5^{\circ} \mathrm{C}$ pada transportasi ikan lele, dan dipengaruhi juga oleh jarak tempuh, semakin lama jarak tempuh transportasi, daya angkut juga menurun.

Keseragaman ukuran ikan yang akan diangkut juga harus menjadi perhatian, ikan kerapu macan akan memangsa yang lainnya meskipun perbedaan ukuran tidak terlalu besar. 
Padat pengangkutan tergantung pada kondisi biologis ikan, suhu media pengangkutan, konsentrasi oksigen terlarut dalam media, sarana, teknik persiapan, dan pengemasan.

\section{KESIMPULAN DAN SARAN}

Transportasi ikan laut hidup sangat penting dalam kegiatan budidaya dan perdagangan ikan laut untuk mendapatkan nilai jual yang lebih tinggi dan meningkatkan nilai hasil usaha.

Teknik transportasi darat, laut, dan udara telah memanfaatkan dasar ilmu biologi, fisika, dan kimia;

- Manipulasi kondisi biologis (pemuasaan) bertujuan pengkondisian untuk menekan aktivitas ikan, pencernaan, dan metabolisme yang berdampak pada menurunnya tingkat konsumsi oksigen dan meminimalisir kotoran, amonia, dan $\mathrm{CO}_{2}$.

- Manipulasi fisik lingkungan, penurunan suhu media pengangkut, bertujuan menekan tingkat aktivitas ikan sehingga terhindar dari stres, menurunkan aktivitas metabolisme, sekresi enzim, penggunaan bioenergi yang berarti kebutuhan oksigen juga menurun.

- Manipulasi kimia air penurunan kadar garam bertujuan untuk menurunkan aktivitas osmoregulasi ikan berkaitan penggunaan bioenergi, serta peningkatan oksigen terlarut dimaksudkan untuk mempertinggi tekanan parsial gas oksigen di dalam air laut media pengangkut, sehingga proses diffusi oksigen kedalam darah menjadi semakin mudah.

Teknik transportasi ikan laut masih perlu ditingkatkan efisiensinya, sehingga padat ikan yang dapat diangkut meningkat per satuan volume dengan jarak tempuh yang semakin jauh, dan menguntungkan secara ekonomi pada usaha budidaya laut.

Untuk mencapai teknologi transportasi yang lebih efisien, masih diperlukan kegiatan penelitian yang lebih mendalam, baik dari aspek biologi untuk mengetahui batas toleransi ikan menurut ukuran dan bobotnya pada berbagai kondisi fisik media pengangkut. Rancang bangun kemasan masih harus diteliti untuk dapat mengatur suhu media, keterlarutan oksigen maupun mengeliminir gasgas bersifat toxic seperti $\mathrm{NH}_{3}$ dan $\mathrm{CO}_{2}$.

\section{UCAPAN TERIMA KASIH}

Dengan ini disampaikan ucapan terima kasih kepada Bapak Amin, Bapak Sukiman (pengusaha budidaya laut) di Belitung atas segala kesempatan, informasi, dan penyelenggaraan kegiatan transportasi yang dapat diikuti, sehingga dihasilkan tulisan ini.
Ucapan terima kasih juga disampaikan kepada Bapak Ketut Arya Sudewa dalam kapasitasnya sebagai teknisi yang telah terjun langsung pada kegiatan transportasi, dan informasi penting yang berhasil dihimpun.

\section{DAFTAR PUSTAKA}

Anonymous. 1986. Training Manual on Marine Finfish Netcage Culture in Singapore. Regional Seafarming Project RAS/86/024. Fisheries and Aquaculture Department of Singapore and FAO. http://www.fao.org/field/ 003/AB705E/AB705E09.htm. 8 pp.

Csavas, L. 1994. World Aquaculture Status and Outlook. Infofish International. 5(94): 47-54.

Fujaya, Y. 2004. Fisiologi Ikan. Dasar Pengembangan Teknik Perikanan. PT Rineka Cipta. Jakarta. 179 pp.

Nurdjana, M.L. 2001. Prospek sea farming di Indonesia. Seminar Teknologi Budidaya laut dan pengembangan sea farming di Indonesia. Departemen Kelautan dan Perikanan bekerja sama dengan Japan International Cooperation Agency (IICA). 9 pp.

Schmittou, H.R. 1991. Cage Culture, A Method of Fish Production in Indonesia. Central Research Institute for Fisheries. Jakarta. 114 pp.

Sudradjat, A., W. Ismail, dan P.T. Imanto. 1999. Pengembangan Marikultur di Indonesia. Makalah disampaikan pada Rapat Kerja Teknis Puslitbang Perikanan. Caringin. 15 pp.

Suparno dan H.E. Irianto. 1995. Transportasi Ikan Hidup dan Teknologi Pascapanen. Prosiding Temu Usaha Pemasyarakatan Teknologi Keramba Jaring Apung Bagi Budidaya Laut. Jakarta. p. 88- 106.

Suryaningrum, T.D., E. Setiabudi, dan M.D. Erlina. 1997. Pengaruh Penurunan Suhu Bertahap terhadap Aktivitas dan Sintasan Lobster Hitam (Panulirus Peniculatus) selama Transportasi Sistem Kering. J. Pen. Perik Indonesia. III(2): 63- 70 .

Suryaningrum, T.D., A. Sari, dan N. Indriati. 2000․․ Pengaruh kapasitas angkut terhadap sintasan dan kondisi ikan pada transportasi kerapu hidup sistem basah dalam Prosiding Seminar Hasil Penelitian Perikanan 1999/2000. Sukamandi. Puslitbang Eksplorasi Laut dan Perikanan. Jakarta. p. 259- 268.

Suryaningrum, T.D., N. Indriati, dan S. Amini. 2000. Penelitian model kemasan transportasi hidup ikan kerapu sistem kering. dalam Prosiding Seminar Hasil Penelitian Perikanan 1999/2000. Sukamandi. Puslitbang Eksplorasi Laut dan Perikanan. Jakarta. p. 278- 284.

Suryaningrum, T.D. dan B.S.B. Utomo. 2001. Ikan Kerapu Hidup: Penanganan dan Transportasinya dalam buku Teknologi Budidaya Laut dan Pengembangan Sea 
Farming di Indonesia. Puslitbang Eksplorasi Laut dan Perikanan, Jakarta. p. 369-381.

Surono, I. Ismanaji, N. Djazuli, dan Sunarya. 1995. Pengujian transportasi ikan hidup dengan metode hibernasi. Prosiding Simposium Perikanan Indonesia I. Puslitbangkan. Jakarta. 37: 1-5.
Wedemeyer, G.A. 1996. Physiology of Fish in Intensive Culture Systems. International Thomson Publishing, Chapman \& Hall. New York. 232 pp. 